\title{
Contextualizando e resgatando a produção e o consumo das Hortaliças Tradicionais (Hortaliças PANC) da biodiversidade brasileira
}

- Na Embrapa Hortaliças, desenvolvemos desde 2006 um trabalho de conservação e promoção do cultivo e do consumo de Hortaliças PANC (Plantas Alimentícias Não Convencionais), entendendo-se o amplo uso como a melhor estratégia de conservação;

- A Embrapa atua junto a parceiros da extensão rural, pesquisa regional e organizações de agricultores na sistematização do cultivo e promoção do cultivo e do consumo das Hortaliças PANC;

- Com a urbanização e a globalização, ocorreram mudanças na sociedade e no padrão de vida, com a perda de referência dos quintais e das roças com Hortaliças PANC e a substituição por espécies, em geral exóticas, com cadeias produtivas organizadas;

- As Hortaliças PANC são notavelmente rústicas, menos exigentes em fertilidade e irrigação, de fácil cultivo e manutenção, muito resilientes e de grande adaptabilidade climática, fundamentais para o enfrentamento dos efeitos das mudanças climáticas;

- Por sua rusticidade, as Hortaliças PANC são eminentemente orgânicas e adequadas à agricultura com altos índices de sustentabilidade em sistemas de base agroecológica;

- Muitas Hortaliças PANC representam verdadeiro resgate cultural, como ora-pro-nóbis, cuxá e jambu, por isso, também são chamadas de Hortaliças Tradicionais, que sofrem, por vezes, processo de extinção alimentar, como mangarito, araruta, ariá e jacatupé;

- As Hortaliças PANC são muito adequadas à agricultura urbana, seja em quintais produtivos ou em hortas comunitárias, pela facilidade de cultivo, baixo uso de insumos, resistência a estresses (falta ou excesso de água e ataque de pragas e doenças) e baixo custo de produção;

- As Hortaliças PANC adequam-se plenamente ao conceito de jardim produtivo ou paisagismo produtivo, com muitas espécies ornamentais, outras cercas vivas, várias de ocorrência espontânea ou de ciclo perene;

- Muitas Hortaliças PANC são verdadeiras iguarias culinárias, apresentando infinitas oportunidades de paladar, valorizadas desde a culinária regional tradicional até a alimentação gourmet e a alta gastronomia;

- As Hortaliças PANC apresentam características nutracêuticas e funcionais destacadas, com resultados impressionantes, mas carecendo ainda de estudos quanto à variabilidade em cada espécie e influências ambientais.

\section{Referências bibliográficas}

1. BRASIL. Ministério da Agricultura, Pecuária e Abastecimento. Manual de hortaliças não-convencionais. Brasília: Mapa / Secretaria de Desenvolvimento Agropecuário e Cooperativismo, 2010. 92 p.

2. BRASIL. Ministério da Saúde. Alimentos regionais brasileiros. 2ª ed. Brasília: MS / Secretaria de Atenção à Saúde, Departamento de Atenção Básica, 2015. $484 \mathrm{p}$.

3. KINUPP, V.F.; LORENZI, H. Plantas alimentícias não convencionais (PANC) no Brasil: guia de identificação, aspectos nutricionais e receitas ilustradas. São Paulo: Instituto Plantarum de Estudos da Flora, 2014. 768 p.

4. MADEIRA, N.R.; SILVA, P.C.; BOTREL, N. et al. Manual de produção de Hortaliças Tradicionais. Brasília, DF: Embrapa, 2013.155 p. 